\title{
MELEBUR DALAM HARMONI DAN KEBERSAMAAN: STUDI KASUS SENSE OF COMMUNITY PADA MASYARAKAT SUB-URBAN KAMPUNG NEGLASARI JATINANGOR
}

\section{Hammad Zahid Muharram}

Fakultas Psikologi Universitas Padjadjaran (UNPAD) Bandung Jawa Barat, Indonesia

Email: zahidmuharram@gmail.com

\begin{abstract}
Abstrak
Kehadiran empat perguruan tinggi di Jatinangor menimbulkan perubahan terhadap kehidupan sosial masyarakat di sekitarnya, termasuk pada aspek rasa komunitas. Rasa komunitas merupakan perasaan bahwa anggota komunitas memiliki keterikatan, keberartian bagi anggota yang lain, dan keyakinan dalam memenuhi kebutuhan melalui komitmen bersama. Penelitian ini bertujuan untuk mengetahui dinamika perilaku sosial masyarakat dan memahami rasa komunitas pada masyarakat sub-urban di Kampung Neglasari Jatinangor. Partisipan yang terlibat dalam penelitian ini berjumlah empat orang yang dipilih menggunakan teknik purposive. Rancangan penelitian menggunakan desain studi kasus tunggal dengan pengumpulan data melalui wawancara dan observasi. Teknik analisis data yang digunakan dalam penelitian ini adalah teknik analisis dengan menggunakan metode analisis tematik. Hasil penelitian menunjukkan bahwa rasa komunitas pada masyarakat sub-urban terbentuk dari rasa kebersamaan, partisipasi masyarakat, keterikatan emosional, dan kepercayaan pada pemimpin masyarakat.
\end{abstract}

Kata Kunci: rasa komunitas; harmoni sosial; masyarakat sub-urban

\section{Abstract}

The presence of four universities in Jatinangor has led to changes in the social life of the surrounding communities, including the aspects of the sense of community. A sense of community is the feeling that community members have attachments, significance for other members, and confidence in fulfilling needs through mutual commitment. This study aims to determine the dynamics of the social behavior of the community and understand the sense of community in suburban communities in Kampung Neglasari Jatinangor. There were four participants involved in this study who were selected using a purposive technique. The design of the study uses a single case study by collecting data through interviews and observations. The data analysis technique utilized in this study using thematic analysis methods. The results of the study show that the sense of community in suburban communities is formed from a sense of togetherness, community participation, emotional attachment, and trust in community leaders.

Keywords: sense of community; social harmony; suburban communities

$\begin{array}{ll}\text { How to cite: } & \text { Muharram. H.Z (2022) Melebur dalam Harmoni dan Kebersamaan: Studi Kasus Sense of Community Pada } \\ & \text { Masyarakat Sub-Urban Kampung Neglasari Jatinangor. Syntax Literate: Jurnal Ilmiah Indonesia, 7(1). } \\ & \text { http://dx.doi.org/10.36418/ Syntax-Literate.v7i1.6053 } \\ \text { E-ISSN: } & \text { 2548-1398 } \\ \text { Published by: } & \text { Ridwan Institute }\end{array}$


Received: 2021-12-20; Accepted: 2022-01-05; Published: 2022-01-15

\section{Pendahuluan}

Pesatnya pertumbuhan Kota Bandung sebagai pusat pemerintahan Provinsi Jawa Barat menyebabkan permasalahan baru di bidang tata ruang dan pertanahan. Keterbatasan ruang dan sumber daya menjadi salah satu penyebab utama kompleksnya permasalahan di Kota Bandung. Untuk mengatasi masalah tersebut, Pemprov Jawa Barat berupaya memindahkan aktivitas pendidikan tinggi ke pinggir Kota Bandung melalui kebijakan Kawasan Pendidikan Tinggi (KPT) Jatinangor untuk mengurangi beban Kota Bandung. Hal ini tertuang dalam Surat Keputusan Gubernur Kepala Daerah Tingkat I Jawa Barat No.583/SK-PIK/1989. Kebijakan tersebut direalisasikan dengan melakukan relokasi empat universitas besar dari Kota Bandung yaitu Institut Manajemen Koperasi Indonesia (IKOPIN) pada tahun 1982, Universitas Padjadjaran (UNPAD) pada tahun 1987, Institut Pemerintahan Dalam Negeri (IPDN) pada tahun 1989, dan Universitas Winaya Mukti (UNWIM) pada tahun 1991. Selain itu, didirikan pula beberapa hotel besar, apartemen, padang golf, dan Bumi Perkemahan Kiarapayung, yang menjadi sarana dan prasarana wisata di wilayah Jatinangor (Nursawitri, Syafriharti, \& Hastini, 2011).

Jatinangor pada awalnya merupakan salah satu kawasan yang secara administratif berada di Kecamatan Cikeruh Kabupaten Sumedang. Penetapan kawasan Jatinangor sebagai kawasan pendidikan tinggi membawa risiko berubahnya Kecamatan Cikeruh dari status kecamatan bernuansa pedesaan yang didominasi pertanian menjadi suatu kawasan kota yang dipadati oleh pembangunan. Kawasan Jatinangor kemudian ditetapkan sebagai kecamatan melalui Peraturan Daerah Kabupaten Sumedang Nomor 51 Tahun 2000 tentang Pembentukan Kecamatan. Hal tersebut juga didukung oleh Keputusan Bupati Sumedang Nomor 6 Tahun 2001 tentang Penetapan Desa dan Kelurahan dalam Wilayah Kecamatan di Kabupaten Sumedang. Pergantian status wilayah di kawasan Jatinangor disahkan pada tanggal 24 Februari 2001 sehubungan dengan adanya pemekaran kecamatan-kecamatan di Kabupaten Sumedang dari 18 kecamatan menjadi 26 kecamatan (Bappeda, 2009).

Kawasan Jatinangor saat ini telah berubah menjadi kota kecil yang terus mengalami perkembangan sejalan dengan fungsinya sebagai lokasi pendidikan. Perkembangan tersebut diawali oleh tumbuhnya permukiman, kegiatan perdagangan di sepanjang Jalan Raya Bandung-Sumedang, serta berbagai jasa bagi mahasiswa. Kawasan Jatinangor yang terbuka bagi para pendatang, baik civitas akademika, maupun profesi lainnya kemudian mengubah kondisi tatanan masyarakat yang ada di dalamnya. Kehadiran pendatang di kawasan Jatinangor pada akhirnya berpeluang memarginalkan penduduk lokal. Hal ini terlihat dari bertambahnya kesenjangan sosial antara penduduk lokal dan pendatang. Secara psikologis, sikap masyarakat mulai berubah menjadi lebih individualistis. Selain itu, pengaruh interaksi antara warga pendatang dengan warga lokal mengakibatkan melemahnya pemahaman terhadap agama, degradasi moral dan retaknya sistem sosial warga lokal (Bappeda, 2009). 
Pada umumnya, warga pendatang mempunyai tempat tinggal yang terhubung dengan kegiatan usaha yang dimiliki. Tempat tersebut biasanya didapatkan dari penghuni lokal dengan sistem sewa/jual. Saat ini Desa Hegarmanah, pemilik/penghuni rumah sepanjang jalan raya Sumedang-Jatinangor adalah warga pendatang, sementara pemilik/penghuni sebelumnya tersingkir ke lokasi lain di luar Jatinangor. Hal tersebut sangat berpengaruh terhadap kehidupan sosial di masyarakat, termasuk rasa memiliki terhadap komunitas (sense of community) masyarakat di kawasan Jatinangor. Dengan demikian, dapat dikatakan bahwa berubahnya status Jatinangor sebagai kawasan pendidikan yang ditandai dengan hadirnya empat perguruan tinggi menimbulkan perubahan terhadap kehidupan dan perilaku masyarakat di sekitarnya.

Theresia (1998) mengemukakan bahwa keberadaan perguruan tinggi di Jatinangor menyebabkan terjadinya pergeseran mata pencaharian penduduk dari sektor pertanian ke sektor jasa dan perdagangan. Penduduk yang tidak memiliki kemampuan untuk bersaing di sektor selain pertanian pada akhirnya kehilangan mata pencahariannya dikarenakan lahan pertaniannya terjual. Hal tersebut membuat sebagian penduduk asli terpaksa meninggalkan wilayah Jatinangor untuk mempertahankan hidup. Sementara itu, ditemukan pula bahwa kehadiran perguruan tinggi di Jatinangor tidak mengubah tingkat pendidikan penduduk. Sebelum dan sesudah adanya perguruan tinggi mayoritas penduduk adalah tamatan Sekolah Dasar (Theresia, 1998). Mardiantara (2001) mengungkapkan bahwa kegiatan ekonomi penunjang perguruan tinggi lebih banyak dilakukan oleh pendatang $(68,5 \%)$ daripada penduduk lokal $(31,5 \%)$.

Berdasarkan hal ini, dapat diasumsikan bahwa adanya perguruan tinggi belum dapat mengurangi tingkat pengangguran bagi penduduk lokal. Justru para pendatanglah yang memperoleh manfaat ekonomi lebih besar dari kehadiran perguruan tinggi di kawasan Jatinangor. Kurangnya pemberdayaan masyarakat berbasis komunitas bisa jadi menjadi penyebab kesenjangan yang terjadi pada penduduk lokal. Nelson \& Prilleltensky (2017) menyatakan bahwa komunitas yang kuat dapat menguntungkan individu, kualitas hidup individu, dan komunitas itu sendiri (intertwined). Identifikasi anggota masyarakat sebagai bagian dari karakteristik komunitas merupakan suatu hal yang dilihat dalam kajian psikologi mengenai komunitas sebagai konsep dari rasa memiliki komunitas (sense of community).

Sense of community menurut McMillan \& Chavis (1986), yaitu "a feeling that members have of belonging, a feeling that members matter to one another and to the group, and a shared faith that members needs will be met through their commitment to be together". Dengan demikian, dapat diartikan bahwa sense of community adalah perasaan bahwa seseorang memiliki rasa saling memiliki, rasa berarti satu sama lain, dan rasa percaya bahwa kebutuhan bersama akan terpenuhi apabila para anggota memiliki komitmen untuk terus bersama. Pendekatan ini menaruh perhatian pada perilaku seseorang, termasuk hubungan seseorang dengan lingkungannya sebagai suatu entitas. Barker (dalam Kloos et al., 2020) menyatakan bahwa setting perilaku merupakan konteks yang meliputi pola tingkah laku dan waktu di dalamnya, oleh karena itu setting dalam lingkungan kampung dapat digolongkan sebagai salah satu 
setting sosial yang memiliki fungsi usaha, pendidikan, agama, dan perkumpulan sukarela, yang dapat mempengaruhi pola tingkah laku warga di dalamnya.

Setting sosial menurut Moos (dalam Rudkin, 2003) memiliki karakteristik tersendiri yang disebut sebagai iklim sosial. Iklim sosial terdiri dari tiga dimensi yang dapat berbeda pada setiap konteks masyarakat, dimensi tersebut yaitu orientasi hubungan, orientasi perkembangan, dan orientasi sistem pemeliharaan atau orientasi perubahan. Orientasi ini padat dilihat pada bagaimana anggota komunitas saling terlibat dalam suatu setting sosial yang mendukung satu sama lain. Dimensi-dimensi tersebut dapat menjadi faktor yang berguna dalam memetakan kondisi psikososial komunitas. Komunitas masyarakat merupakan subjek pembangunan yang dapat dipenuhi kesejahteraannya di tingkat individu melalui rasa memiliki komunitas (sense of community) sebagai indikator kesejahteraan di tingkat komunal (Prilleltensky \& Prilleltensky, 2006). Keterkaitan individu dengan lingkungannya dapat dilihat sebagai iklim sosial yang dapat mempengaruhi tingkah laku individu di dalam setting sosial. Penelitian ini berfokus pada aspek psikososial dari karakter komunitas berkaitan dengan faktor demografi yang mempengaruhi rasa komunitas (sense of community) masyarakat dalam kerangka pengembangan masyarakat.

Kampung Neglasari yang berada di Desa Hegarmanah merupakan salah satu kampung yang termasuk dalam wilayah sub-urban Kecamatan Jatinangor. Hal ini dikarenakan letak kampung yang berada di pinggir wilayah perkotaan dan berbatasan langsung dengan wilayah pedesaan. Selain itu kampung ini juga berada dekat dengan kawasan pendidikan tinggi sehingga masuknya pendatang untuk menanam investasi di lingkungan kampung lambat laun mempengaruhi kultur masyarakat, termasuk sense of community di dalamnya. Berdasarkan fenomena tersebut, peneliti merancang penelitian ini dengan tujuan untuk mengetahui dinamika perilaku sosial masyarakat dan memahami gambaran sense of community pada masyarakat sub-urban di Kampung Neglasari Jatinangor. Hasil dari penelitian ini diharapkan dapat menjadi salah satu kontribusi pada perkembangan teori sense of community, serta menjadi pertimbangan bagi pihak-pihak seperti pemangku kebijakan di tingkat daerah, community developer, serta peneliti lain untuk mengembangkan program intervensi dalam rangka pemberdayaan dan pengembangan masyarakat di wilayah sub-urban.

\section{Metode Penelitian}

Metode dalam penelitian ini menggunakan metode kualitatif dengan pendekatan studi kasus. Studi kasus menurut Creswell (2015) merupakan suatu pendekatan yang menekankan pada eksplorasi dari suatu sistem yang berbatas (bounded system) dengan berusaha untuk mengungkap, mempelajari, dan memahami suatu kasus secara mendetail disertai dengan penggalian data secara mendalam yang melibatkan berbagai sumber informasi yang kaya akan konteks. Berdasarkan kekhasan kasus yang diteliti mengenai rasa komunitas, peneliti menggunakan desain studi kasus tunggal (single case) yang memungkinkan peneliti untuk melakukan eksplorasi secara spesifik dan mendalam tentang kejadian tertentu dari sebuah fenomena. Subjek penelitian dipilih dengan 
menggunakan teknik purposive. Pada teknik purposive, pemilihan sekelompok subjek didasarkan atas ciri-ciri atau sifat-sifat tertentu. Peneliti secara intensional hanya mengambil satu daerah atau kelompok kunci.

Metode pengumpulan data dilakukan dengan menggunakan wawancara dan observasi. Wawancara dilakukan kepada empat partisipan yang seluruhnya merupakan masyarakat asli Kampung Neglasari Jatinangor. Sementara, observasi dilakukan dengan mengamati lingkungan kampung dan karakteristik wilayah yang diteliti. Sebelum dilaksanakan penelitian, peneliti menyampaikan penjelasan mengenai rangkaian proses penelitian dan memberikan informed consent kepada seluruh partisipan. Penelitian ini menggunakan empat partisipan yang tinggal dalam satu lingkungan masyarakat, serta menjadikan setting di lingkungan sosial masyarakat sebagai lokasi pengambilan data. Data partisipan disajikan dalam Tabel 1 sebagai berikut:

\section{Tabel 1}

\section{Data Profil Partisipan}

\begin{tabular}{cccc}
\hline Inisial & Usia & Jenis Kelamin & Status \\
\hline US & 50 Tahun & Laki-laki & Ketua RW \\
TAF & 66 Tahun & Laki-laki & Tokoh Masyarakat \\
DS & 54 Tahun & Laki-laki & Pengurus DKM \\
TRN & 53 Tahun & Perempuan & Warga \\
\hline
\end{tabular}

Adapun teknik analisis data yang digunakan peneliti dalam penelitian ini adalah teknik analisis dengan menggunakan pendekatan analisis tematik. Braun \& Clarke (2006) menjelaskan bahwa analisis tematik merupakan sebuah teknik analisis dalam penelitian kualitatif yang dapat digunakan untuk mengidentifikasi, menganalisis, melaporkan pola-pola yang terdapat dalam data, dan menyajikannya dengan tema yang rinci dalam data. Analisis tematik menurut Braun \& Clarke (2006) terdiri dari beberapa tahapan sebagai berikut: (1) Mengumpulkan dan memahami data yang diperoleh secara utuh; (2) Memberikan entri penomoran dan melakukan pengkodean data awal; (3) Mengelompokkan data terpilih menjadi pola-pola dan mencari tema; (4) Melakukan review terhadap tema; (5) Mendefinisikan tema dan menentukan nama tema utama; dan (6) Menyusun laporan penelitian. Seusai semua tahapan penelitian tersebut dilakukan, peneliti berfokus pada interpretasi hasil penelitian dengan melihat kembali kasus secara holistik, serta mencocokkan dengan dokumen dan observasi yang ada. Peneliti kemudian menganalisis dengan teori-teori yang relevan dan menyajikannya dalam bentuk laporan penelitian narasi khas studi kasus.

\section{Hasil dan Pembahasan}

Peneliti memberikan gambaran anteseden kasus berupa sejarah singkat, lanskap dan demografi kampung untuk membantu memahami fenomena sense of community pada kampung yang diteliti. Berdasarkan sejarahnya, kampung Neglasari merupakan sebuah Rukun Warga yang terletak di Desa Hegarmananah Kecamatan Jatinangor. Pada awalnya dusun ini bernama Narongtong yang berada di perbatasan antara dua kampung, 
dan termasuk dalam wilayah administrasi Dusun Cikajang Desa Cileles. Adanya pergantian kepengurusan RW, membuat masyarakat berinisiatif untuk mengubah nama kampungnya menjadi kampung Neglasari, lalu kemudian meleburkan diri di bawah administrasi Desa Hegarmanah. Kampung Neglasari resmi berdiri pada awal tahun 1983 dengan mayoritas masyarakat bermata pencaharian sebagai petani yang menggarap lahan di sekitar kampung.

Secara harfiah, Negla dapat berarti sebuah tempat yang berada di atas, sedangkan Sari dapat berarti inti utama. Hal ini menggambarkan kondisi fisik kampung yang merupakan kumpulan masyarakat yang berada di atas sebuah bukit. Saat ini, penduduk Neglasari terbagi ke dalam lima Rukun Tetangga. Jumlah penduduk tercatat di kisaran \pm 1000 jiwa dan terbagi ke dalam $\pm 300 \mathrm{KK}$. Seluruh warga kampung menganut agama Islam dan menerapkan budaya-budaya Sunda. Sementara itu, mata pencaharian masyarakat saat ini sudah mulai beralih dari pertanian ke arah wiraswasta, sebagian menjadi buruh lepas dan buruh pabrik dan hanya sebagian kecil dari jumlah penduduk yang tercatat masih berprofesi sebagai petani. Perubahan mulai terasa setelah Universitas Padjadjaran dibangun pada tahun 1988 di Kawasan Desa Hegarmanah. Hal ini ditandai dengan populasi penduduk yang semakin meningkat, ditambah pembangunan sarana dan prasarana masyarakat yang semakin meningkat. Nilai harga tanah yang sebelumnya rendah juga bertambah secara signifikan, sehingga banyak orang luar yang berdatangan untuk melakukan investasi di Kampung Neglasari. Saat ini, telah banyak hunian mahasiswa yang berdiri di kampung ini, dari mulai indekos, apartemen, hingga vila. Lanskap Kampung Neglasari Jatinangor dapat dilihat pada

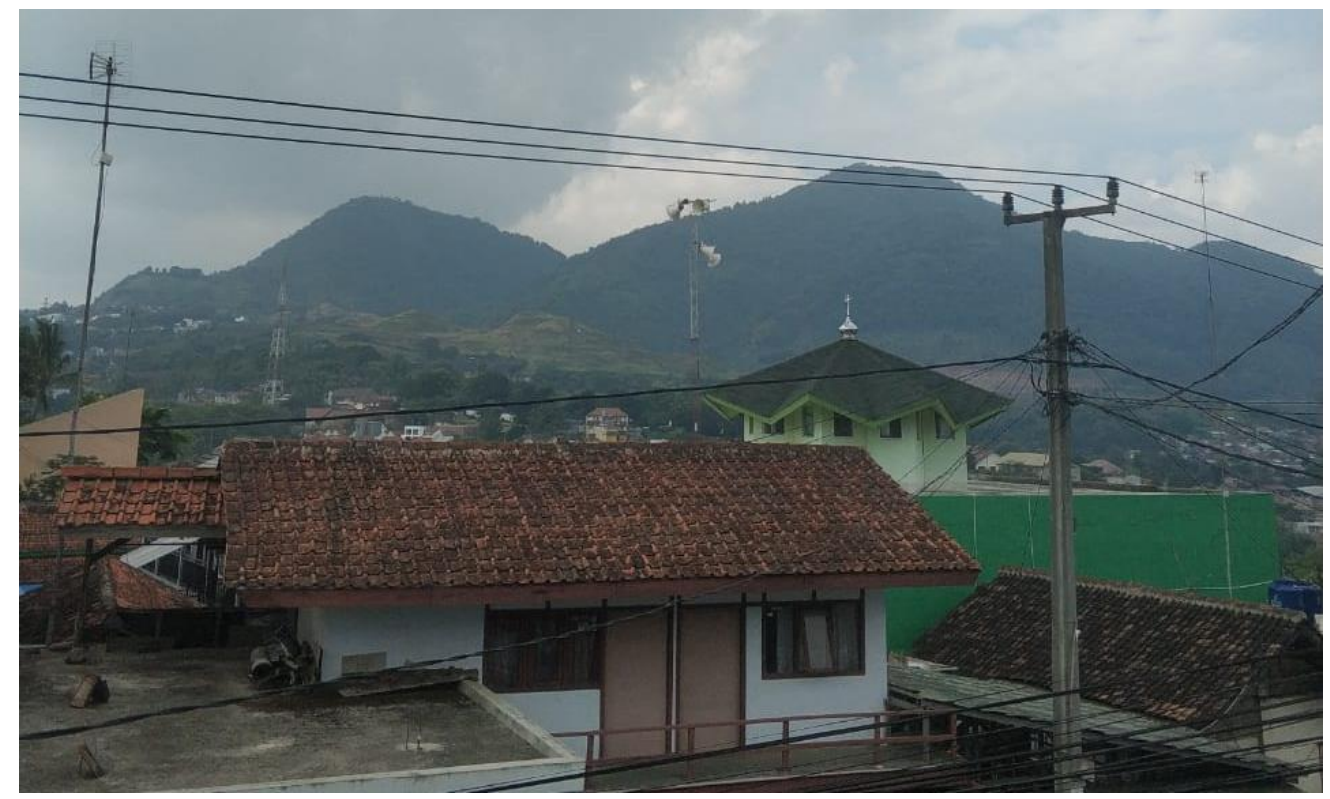

\section{Gambar 1}

\section{Lanskap Kampung Neglasari}

Pendekatan studi kasus dalam pengolahan data kualitatif dijalankan dengan menemukan fakta pada data dan menentukan kode-kode yang kemudian dijadikan kategorisasi tema. Selanjutnya, peneliti memakai istilah tema minor dan tema mayor 
untuk menjelaskan kerangka yang seragam. Tema minor merupakan tema yang muncul dari kumpulan kategori, sedangkan tema mayor merupakan tema yang muncul dari serangkaian tema minor. Penggunaan istilah tema mayor dan minor dimaksudkan untuk lebih memudahkan pembaca dalam memahami hasil penelitian. Penelitian ini berhasil mengidentifikasi empat tema mayor dengan masing-masing tiga tema minor yang disajikan dalam Tabel 2 sebagai berikut:

\section{Tabel 2}

Tema Mayor dan Tema Minor Kasus

\begin{tabular}{cl}
\hline Tema Mayor & \multicolumn{1}{c}{ Tema Minor } \\
\hline \multirow{2}{*}{ Rasa Kebersamaan } & Upaya saling mengenal satu sama lain \\
& Sikap saling tolong menolong antar masyarakat \\
& Upaya untuk menjaga kerukunan \\
\hline \multirow{3}{*}{ Keterikatan Emosional } & Rasa kekeluargaan antar anggota masyarakat \\
& Saling berbagi pengalaman emosional \\
& Pemenuhan harapan-harapan bersama \\
\hline \multirow{2}{*}{ Partisipasi Masyarakat } & Upaya pemenuhan kebutuhan bersama \\
& Kontribusi pada kegiatan masyarakat \\
& Saling berkolaborasi \\
\hline \multirow{2}{*}{ Kepercayaan pada } & Pemimpin sebagai pengayom masyarakat \\
Pemimpin & Pemimpin mampu menyelesaikan masalah masyarakat \\
& Pandangan positif masyarakat kepada pemimpin \\
\hline
\end{tabular}

Berdasarkan wawancara pada empat partisipan, rasa kebersamaan digambarkan sebagai upaya saling mengenal satu sama lain, sikap saling tolong menolong, dan upaya menjaga kerukunan. Pada masyarakat Kampung Neglasari, proses pengenalan individu didasari dengan proses identifikasi bentuk fisik tubuh. Seperti misalnya seorang anggota masyarakat yang akrab dipanggil Ableh karena ciri fisiknya yang dobleh (Bapak US). Masyarakat merasa lebih akrab apabila memanggil anggota masyarakat yang lain dengan menggunakan identitas yang telah dibuat bersama dibandingkan dengan memanggil nama asli. Rasa tersinggung sama sekali tidak ditunjukkan oleh masyarakat yang identitasnya telah diganti dengan sapaan akrab.

Sikap saling tolong menolong juga ditunjukkan oleh masyarakat sebagai bentuk rasa kebersamaan masyarakat di dalam lingkup komunitas. Masyarakat masih kerap melakukan kerja bakti untuk membangun fasilitas kampung ataupun menjaga kebersihan kampung. Selain itu, budaya saling membantu juga ditunjukkan saat ada masyarakat yang hendak membangun rumah. Masyarakat terbiasa untuk bergotong royong saling membantu dalam pembangunan rumah (Bapak US). Apabila ada kegiatan seperti hajatan, tasyakuran, dan layat yang diadakan oleh salah satu anggota masyarakat, maka anggota masyarakat yang lain berupaya untuk terlibat sebagai pemberi bantuan secara moril maupun materiil (Bapak DS).

Rasa kebersamaan masyarakat juga ditunjukkan dengan upaya untuk menjaga kerukunan antara satu anggota masyarakat dengan anggota yang lain. Interaksi yang harmonis selalu dijaga ketika masyarakat menjalin relasi. Masyarakat yang memiliki potensi lebih banyak dan memiliki keahlian tertentu secara langsung berfungsi sebagai 
media belajar bagi anggota yang lain. Dengan demikian, apabila ada perbedaan hobi dan minat pada sebagian masyarakat, maka anggota masyarakat yang lain akan tetap berbaur bersama-sama (Bapak US). Masyarakat mengistilahkan hal tersebut sebagai perilaku guyub rukun, yaitu adanya hubungan harmonis antar anggota dalam komunitas.

Tema mayor selanjutnya yaitu keterikatan emosional. Tema ini menggambarkan rasa kekeluargaan antar anggota masyarakat, sikap saling berbagi pengalaman emosional, dan upaya pemenuhan harapan bersama. Rasa kekeluargaan masyarakat ditunjukkan dengan upaya untuk membangun rasa percaya. Kepercayaan antar warga ini yang dijadikan landasan bagi masyarakat untuk membangun hubungan emosional. Dengan adanya rasa kekeluargaan sebagai perasaan saling memiliki antar anggota masyarakat, maka apabila terjadi konflik di masyarakat, penyelesaian konflik tersebut diupayakan melalui mekanisme kekeluargaan. Jalan yang diambil masyarakat adalah menggunakan sistem musyawarah untuk mengambil solusi dari setiap permasalahan.

Masyarakat semakin menguatkan ikatan emosional dengan saling berbagi pengalaman emosional bersama-sama. Pengalaman tersebut dilandasi dengan nilai-nilai keislaman yang dianut oleh masyarakat. masyarakat merasa bahwa apabila interaksi dilakukan mengacu pada prinsip silaturahmi, maka hasil yang didapat juga merupakan sebuah keberkahan. Suasana lingkungan masyarakat juga akan terasa aman, nyaman, dan tenteram apabila prinsip yang dipegang adalah prinsip keislaman (Bapak DS). Kondisi masyarakat yang sepenuhnya menganut agama Islam membuat masyarakat dengan mudah berbagi pengalaman dengan nilai-nilai agama tersebut. Masjid digunakan sebagai tempat sentral bagi masyarakat untuk berbagi pengalaman emosional (Ibu TRN).

Ikatan emosional masyarakat di Kampung Neglasari juga berkaitan dengan harapan-harapan bersama para masyarakat terhadap wilayahnya. Partisipan penelitian hampir seluruhnya memiliki harapan agar lingkungan kampung damai dan makmur. Kondisi ideal yang diharapkan oleh masyarakat adalah terciptanya masyarakat yang agamis. Untuk mencapai hal tersebut, maka masyarakat berupaya untuk saling mengingatkan dalam hal kebaikan, seperti dengan mengajak ke masjid dan mengikuti pengajian (Ibu TRN). Beragam karakter masyarakat pada akhirnya dapat di satukan melalui pendekatan agama yang dilakukan oleh orang-orang yang berpengaruh dalam komunitas (Bapak TAF). Masyarakat berharap lingkungan mereka dapat menjadi percontohan bagi kampung lain.

Berdasarkan temuan pada penelitian ini, adanya partisipasi masyarakat juga mempengaruhi sense of community di Kampung Neglasari. Partisipasi kolektif masyarakat tersebut ditunjukkan dengan upaya pemenuhan kebutuhan bersama, berkontribusi pada kegiatan masyarakat, dan upaya untuk saling berkolaborasi. Dalam memenuhi kebutuhan bersama, masyarakat mengupayakan agar kesejahteraan dapat merata pada setiap bagian dari komunitas. Adanya tabungan kampung yang posisi sentralnya berada di masjid membuat warga bisa saling membantu dengan cara menabung, dari tabungan tersebut masyarakat yang memiliki kebutuhan mendesak dapat meminjam tanpa dibebankan bunga (Ibu TRN). Masyarakat juga mengupayakan 
diadakannya santunan kepada anak yatim sebagai usaha untuk saling menyejahterakan anggota komunitas. Melalui upaya pemenuhan kebutuhan bersama ini, masyarakat dapat terhindar dari adanya kesenjangan ekonomi.

Partisipasi Masyarakat dalam menjaga keberlangsungan lingkungan sosial kerap ditunjukkan dengan adanya kontribusi pada kegiatan bersama. Masyarakat memiliki beberapa kegiatan bersama yang dilakukan untuk merayakan hari besar Islam dan harihari nasional. Kegiatan tersebut di antaranya Maulid Nabi, Isra' Mi'raj, Tahun Baru Islam, peringatan hari kemerdekaan, hari sumpah pemuda, dan lain sebagainya. Setiap elemen masyarakat dari mulai anak-anak, pemuda hingga orang-orang tua saling berupaya untuk meramaikan kegiatan tersebut (Bapak US). Masyarakat pada umumnya menunjukkan inisiatif untuk berkontribusi dalam keberjalanan kegiatan. Inisiatif masyarakat ditunjukkan dengan membentuk panitia kegiatan secara kolektif. Selain itu, masyarakat juga saling membantu pemenuhan kebutuhan finansial kegiatan dengan cara mengumpulkan iuran bersama (Bapak DS).

Perbedaan keahlian dan status pendidikan tidak menjadikan masyarakat terpecahpecah ke dalam kubu-kubu. Melalui musyawarah, masyarakat dapat memutuskan peran yang akan mereka ambil untuk berbakti di lingkungan Kampung (Bapak DS). Masyarakat juga mengupayakan untuk hadirnya sikap saling berkolaborasi antara elemen pemuda dan orang tua. Elemen orang tua yang pada umumnya lebih aktif di pemerintahan kampung dan kegiatan keagamaan tetap menghargai pemuda yang lebih menyukai kegiatan keolahragaan dan kesenian. Hal ini terlihat dari adanya dukungan masyarakat terhadap aktivitas kesenian reak yang merupakan kesenian khas kampung (Bapak TAF). Kampung Neglasari berusaha menunjukkan identitas kampungnya dengan cara menyatukan seluruh aspek dari mulai kesenian hingga kebudayaan. Hasilnya, pada sebuah kegiatan karnaval yang diselenggara-kan oleh kecamatan, kampung ini berhasil membawa $75 \%$ warganya untuk menjadi peserta karnaval, hingga pada akhirnya meraih predikat kampung terfavorit (Bapak US). Masyarakat selalu berupaya agar setiap elemen dapat saling merangkul elemen yang lainnya.

Berdasarkan temuan, diketahui bahwa pemimpin kampung memiliki peran sentral dalam mempengaruhi sense of community masyarakat. Kepercayaan masyarakat pada pemimpin kampung didasari pada peran pemimpin yang mampu mengayomi masyarakat dan membantu menyelesaikan masalah di masyarakat, sehingga masyarakat cenderung memberikan pandangan positif kepada pemimpinnya. Pemimpin kampung Neglasari yang juga merupakan ketua RW 11 dikenal oleh masyarakat dengan gaya kepemimpinannya yang khas dan mudah berbaur dengan semua kalangan (Ibu TRN). Pemimpin bersama dengan tokoh masyarakat mampu berperan sebagai sosok pemberi nasihat di setiap lini kehidupan warga kampung. Selain itu, pemimpin juga berperan sebagai pribadi yang turut menyiarkan agama di lingkungan kampung (Bapak TAF). Prinsip utama dari pemimpin Kampung Neglasari adalah terciptanya kondisi yang seimbang antara dunia dan akhirat. Hal ini ditunjukkan oleh Ketua RW sebagai pengayom yang cenderung tidak membedakan masyarakat berdasarkan status sosial atau hobi yang diminati masyarakat. 
Adanya kondisi masyarakat yang majemuk membuat dinamika yang muncul di lingkungan masyarakat juga cenderung beragam. Permasalahan berupa perselisihan antara satu anggota masyarakat dengan masyarakat yang lain bisa saja terjadi meskipun frekuensinya sangat jarang. Pada situasi demikian, ketua RW berfungsi sebagai mediator bagi masyarakat yang terlibat perselisihan. Selain itu, Ketika terjadi permasalahan di lingkup kampung, Ketua RW juga memainkan peran sebagai sosok yang mampu membantu dalam penyelesaian masalah. Apabila ada aspirasi dari masyarakat yang ditujukan pada pemerintahan kampung maupun desa, maka Ketua RW turut membantu menyalurkan aspirasi tersebut dengan cara berdiskusi bersama seluruh elemen masyarakat.

Pandangan masyarakat kepada pemimpin cenderung positif seiring dengan dedikasi yang ditunjukkan pemimpin kepada masyarakat. Masyarakat merasa puas dan bangga memiliki pemimpin yang mampu menebarkan energi positif kepada setiap warganya. Tingginya komitmen serta jiwa tanggung jawab Ketua RW terhadap wilayah membuat rasa kepercayaan masyarakat pada pemimpin semakin meningkat. Hal ini dibuktikan dengan terpilihnya Ketua RW yang sama selama dua periode kepengurusan. Ketua RW dianggap sebagai role model bagi masyarakat. Masyarakat memandang Ketua RW sebagai individu yang memiliki kepedulian tinggi, memiliki pengetahuan agama yang baik, dan mampu untuk menjalankan fungsi pemerintahan dengan maksimal (Bapak DS). Dengan demikian, banyak masyarakat yang pada akhirnya terpengaruh dengan perilaku positif yang ditularkan oleh pimpinan masyarakat.

Konstruk teoritis mengenai sense of community dalam kajian psikologi komunitas banyak dikutip dari teori psychological sense of community yang disampaikan oleh McMillan \& Chavis (1986). Konstruk teoritis ini telah dijadikan sebagai sebuah alat ukur psikologi bernama sense of community index dan diadaptasi ke dalam kuesioner oleh Wright (2004). Meskipun demikian, penggunaan metode kuantitatif untuk mempelajari sense of community dianggap kurang mampu mengeksplorasi konteks dan faktor ekologi di dalam komunitas. Penelitian ini berupaya untuk menelaah temuan lapangan mengenai sense of community di Kampung Neglasari dengan meninjau teori yang sudah ada. Menurut Chavis et al. (dalam Wright, 2004), sense of community merupakan perasaan saling memiliki dan terikat antara satu individu dengan individu lainnya di dalam lingkungan masyarakat, dan kepercayaan masyarakat bahwa kebutuhan dari masing-masing individu dalam masyarakat akan terpenuhi selama ada komitmen untuk terus bersama

Dimensi-dimensi yang membentuk sense of community di antaranya: (1) membership yang berarti anggota dalam satu lingkungan masyarakat memiliki perasaan saling memiliki dengan masyarakat dan juga merasa aman untuk menceritakan perasaan atau pendapatnya kepada anggota lain, (2) influence yang berarti anggota masyarakat dapat tertarik ke dalam suatu kelompok dan merasa bahwa dirinya menjadi sosok yang berpengaruh terhadap kelompok tersebut, (3) integration and fulfillment of needs yang berarti anggota masyarakat dapat membagi dan menyalurkan nilai yang mereka punya melalui community involvement dan mampu berpartisipasi dengan sebuah kelompok 
kecil dalam lingkungannya karena kebutuhan anggota tersebut cocok dengan anggota lain di dalam kelompok, dan (4) shared emotional connection yaitu anggota masyarakat dapat bersama-sama saling berbagi komitmen dan kepercayaan satu sama lain, serta berbagi sejarah, tempat, waktu, dan pengalaman emosional bersama (Chavis et al. dalam Wright, 2004).

Hasil dari penelitian ini menunjukkan bahwa sense of community merupakan sebuah konsep yang dapat berubah-ubah tergantung dari konteks yang membangun komunitas. Sense of community dapat menjadi bagian dari komunitas yang akan memperlihatkan bagaimana keterikatan individu terhadap tempat tinggalnya. Pada komunitas masyarakat Kampung Neglasari, sense of community dapat berarti sebagai perasaan kebersamaan dan saling percaya antara satu masyarakat dengan masyarakat lain yang terjalin dalam satu ikatan emosional, serta diwujudkan melalui partisipasi bersama. Keberadaan sense of community akan memunculkan kekompakan pada sistem masyarakat yang merupakan salah satu indikator kesejahteraan masyarakat di tingkat komunal (Prilleltensky \& Prilleltensky, 2006). Hal ini sesuai dengan penelitian yang dilakukan oleh Cicognani et al. (2012) yang memaparkan tentang pentingnya peran sense of community dalam meningkatkan partisipasi sosial dan meningkatkan kesejahteraan sosial.

Komponen yang ada dalam teori yang dikemukakan oleh McMillan \& Chavis (1986) memiliki beberapa persamaan dengan temuan penelitian. Hal ini terlihat dari adanya kebersamaan dan perasaan saling memiliki yang sesuai dengan dimensi membership, adanya pemenuhan kebutuhan bersama, serta adanya ikatan emosional pada masyarakat. Satu hal yang membedakan antara teori dengan temuan di lapangan adalah adanya pemimpin komunitas sebagai tokoh sentral yang paling berpengaruh bagi komunitas. Selain itu, teori sense of community yang dikemukakan oleh McMillan \& Chavis (1986) juga belum mampu menjelaskan mengenai faktor hadirnya anggota baru dan nilai-nilai baru dalam komunitas yang turut mempengaruhi sense of community. Padahal dalam konteks wilayah sub-urban seperti Kampung Neglasari Jatinangor, sense of community merupakan suatu konsep yang dapat digunakan untuk mengamati perubahan praktis kehidupan sehari-hari di antara masyarakat yang berbeda budaya (Barbieri \& Zani, 2015).

Penelitian psikologis tentang sense of community yang menggunakan partisipan penelitian dari masyarakat sub-urban bukan baru pertama kali ini dilakukan. Glynn (dalam Brodsky \& Marx, 2001) mengungkapkan bahwa komunitas sub-urban tercipta berdasarkan tiga konsep, yaitu kesadaran untuk merefleksikan hubungan sesama anggota dan membedakan yang tidak termasuk dalam anggota masyarakat. Kedua, terdapat sebuah tradisi yang merefleksikan norma dan nilai dari perilaku masyarakat, dan yang ketiga adalah tanggung jawab moral yang merefleksikan rasa kewajiban pada lingkungan komunitas dan kewajiban pada sesama anggota di dalam kehidupan masyarakat. Hal-hal tersebut sesuai dengan temuan yang ada di Kampung Neglasari, di mana anggota baru komunitas melakukan konsep-konsep refleksi terhadap hubungan, 
norma, dan kewajiban agar mampu memiliki sense of community yang seimbang dengan anggota yang telah lama berada di komunitas.

Lebih lanjut, terdapat penelitian lain yang mengungkapkan bahwa sense of community pada level personal cenderung mempengaruhi kesejahteraan emosional seseorang (Coulombe \& Krzesni, 2019). Hal ini sesuai dengan temuan penelitian yang menunjukkan bahwa pada masyarakat sub-urban, sense of community justru dipandang sebagai sebuah ikatan emosional yang kemudian dimanifestasikan dalam relasi yang harmonis antar masyarakat. Meskipun demikian, kondisinya semakin terkikisnya ruang alam dan perubahan fungsi lahan pada lingkungan yang dihuni oleh masyarakat suburban dapat berpotensi untuk menghadirkan permasalahan isolasi sosial di kemudian hari, dikarenakan terbatasnya ruang yang dapat dimanfaatkan bersama oleh komunitas (Rugel et al., 2019). Hal tersebut kemudian diperkuat oleh penelitian oleh Ross \& Searle (2019) yang mengungkapkan bahwa tingginya intensitas aktivitas sosial pada masyarakat turut mempengaruhi tumbuhnya sense of community, sehingga dapat disimpulkan bahwa potensi berkurangnya aktivitas bersama sebagai akibat dari berkurangnya ruang sosial masyarakat dapat berpengaruh pada turunnya sense of community pada masyarakat sub-urban di kemudian hari.

\section{Kesimpulan}

Berdasarkan temuan penelitian, dapat disimpulkan bahwa sense of community pada masyarakat sub-urban Kampung Neglasari terbentuk dari rasa kebersamaan, keterikatan emosional, partisipasi masyarakat, dan kepercayaan pada pemimpin masyarakat. Dengan demikian, dapat dikatakan konstruk teoritis sense of community dalam perspektif komunitas secara global memiliki kesamaan dengan konsep sense of community pada masyarakat sub-urban di Kampung Nelasari Jatinangor. Perbedaannya adalah perspektif masyarakat di Kampung Neglasari lebih menekankan pada pencapaian keseimbangan nilai-nilai sebagai sebuah konsep sense of community, serta adanya peran sentral pemimpin dalam mempengaruhi tinggi rendahnya sense of community pada masyarakat. Keberadaan sense of community pada komunits, telah terbukti dapat memunculkan perilaku kolektif pada sistem masyarakat yang merupakan salah satu indikator kesejahteraan di tingkat komunal. Meskipun demikian, perlu dilakukan pemberdayaan masyarakat untuk mengantisipasi fenomena berkurangnya ruang sosial dan aktivitas bersama pada masyarakat sub-urban yang dapat berakibat pada menurunnya sense of community di kemudian hari.

Penelitian ini masih memiliki beberapa keterbatasan. Pada penelitian ini peneliti hanya melibatkan beberapa masyarakat Kampung Neglasari sebagai bagian dari variabel demografi. Analisis yang dilakukan dalam penelitian ini juga seluruhnya berdasarkan pada pandangan subjektif masyarakat Kampung yang terlibat sebagai partisipan dalam penelitian. Meskipun peneliti berusaha untuk seobyektif mungkin dalam melakukan penelitian, namun posisi partisipan penelitian yang mayoritas merupakan orang-orang yang berpengaruh di Kampung berpeluang memunculkan perspektif yang cenderung seragam. Oleh karena itu, peneliti menyarankan kepada 
Melebur dalam Harmoni dan Kebersamaan: Studi Kasus Sense of Community pada Masyarakat Sub-urban Kampung Neglasari Jatinangor

peneliti selanjutnya untuk melakukan penelitian menggunakan metode kualitatif dan kuantitatif (mix method) untuk memperkaya temuan penelitian. 


\section{BIBLIOGRAFI}

Bappeda. (2009). Laporan Akhir Studi Kelayakan Kawasan Jatinangor Sebagai Kawasan Perkotaan. Sumedang: Badan Perencanaan Daerah Sumedang. Google Scholar

Barbieri, I., \& Zani, B. (2015). Multiple sense of community, identity and wellbeing in a context of multi culture: A mediation model. Community Psychology in Global Perspective, 1(2), 40-60. Google Scholar

Braun, V., \& Clarke, V. (2006). Using thematic analysis in psychology. Qualitative Research in Psychology, 3(2), 77-101. h Google Scholar

Brodsky, A., \& Marx, C. (2001). Layers of Identity: Multiple psychological sense of community setting. Journal of Community Psychology, 29(2), 161-178. Google Scholar

Cicognani, E., Zani, B., \& Albanesi, C. (2012). Sense of community in adolescence. Global Journal of Community Psychology Practice, 3(4), 119-125.

Coulombe, S., \& Krzesni, D. (2019). Associations between sense of community and wellbeing: A comprehensive variable and person-centered exploration. Journal of Community Psychology, 47(5), 1246-1268. Google Scholar

Creswell, J. W. (2015). Penelitian Kualitatif dan Desain Riset: Memilih di antara Lima Pendekatan. Yogyakarta: Pustaka Pelajar. Google Scholar

Kloos, B., Hill, J., Thomas, E., Wandersman, A., Case, A., \& Scott, V. (2020). Community psychology: Linking individuals and communities (4th ed.). Washington DC: American Psychological Association.

Mardiantara, A. (2001). Identifikasi Awal Dampak Kegiatan Pendidikan Tinggi pada Ekonomi Lokal di Jatinangor. Tesis. Bandung: Institut Teknologi Bandung.

McMillan, D. W., \& Chavis, D. M. (1986). Sense of Community: A Definition and Theory. American Journal of Community Psychology, 14(1), 6-23. Google Scholar

Nelson, G., \& Prilleltensky, I. (2017). Community Psychology: In pursuit of Liberation and Well-Being. New York: Palgrave Macmillan. Google Scholar

Nursawitri, E., Syafriharti, R., \& Hastini, L. (2011). Pengaruh Kegiatan Perguruan Tinggi Terhadap Tingkat Pelayanan Jalan. Jurnal Ilmiah Unikom, 9(2), 179-186. Google Scholar

Prilleltensky, I., \& Prilleltensky, O. (2006). Promoting Well-Being: Linking Personal, Organizational, and Community Change. New Jersey: John Wiley \& Sons Inc. Google Scholar 
Ross, A., \& Searle, M. (2019). A Conceptual Model of Leisure Time Physical Activity, Neighborhood Environment, and Sense of Community. Environment and Behavior, 51(6), 749-781. Google Scholar

Rudkin, J. K. (2003). Community psychology: Guiding Principles and Orienting Concept. New Jersey: Upper Saddle River. Google Scholar

Rugel, E., Carpiano, R., Henderson, S., \& Brauer, M. (2019). Exposure to natural space, sense of community belonging, and adverse mental health outcomes across an urban region. Environmental Research, 171, 365-377. Google Scholar

Theresia, H. (1998). Dampak Kegiatan Perguruan Tinggi Terhadap Perkembangan Kota Jatinangor. Tesis. Bandung: Institut Teknologi Bandung.

Wright, S. P. (2004). Exploring Psychological Sense Of Community In Living-Learning Programs And In The University As A Whole. Disertasi. Fakultas Pascasarjana Universitas Maryland. Google Scholar

\section{Copyright holder:}

Hammad Zahid Muharram (2022)

First publication right:

Syntax Literate: Jurnal Ilmiah Indonesia

This article is licensed under: 